\title{
Sustainability of Capture Fisheries and SDG 14: Life Below Water*
}

\author{
JOEL ATKINSON* AND LUISA COOLS $^{* * *}$
}

\begin{abstract}
Unlike the Millennium Development Goals (MDGs), the new United Nations (UN) post-2015 Global Sustainable Development Goals (SDGs) include a goal related to conserving and sustainably using the oceans, seas and marine resourcesSustainable Development Goal 14: "Life Below Water" (SDG 14). Inter alia, the goal aims to increase the sustainability of capture fisheries. For the most part, the sub-goals and targets emerging from this process are not new. Still, for the first time, fisheries have moved toward the center of the sustainable development discourse and the high profile of the SDGs may contribute to increased accountability. However, unless rhetoric translates into the political will to set measurable targets and enforce them, the goal alone cannot generate sustainability in capture fisheries.
\end{abstract}

Keywords: SDG, Sustainability, Marine Resources, Fisheries, Fishing

* This article grew out of a paper delivered by the authors at the "Moving from the MDGs to the SDGs" conference at Yonsei University, Wonju, May 20, 2016. The initial exploration of the concepts had a beginning in Atkinson, J., 'The Governance of Capture Fisheries and the Sustainable Development Goals,' MDGs 의 성과와 SDGs의 미래 (Seoul: Kyobo, 2016), pp. 277-310. This work was supported by Hankuk University of Foreign Studies Research Fund.

** Assistant Professor, Hankuk University of Foreign Studies, Seoul, South Korea;

Email: joel.atkinson@hufs.ac.kr;

*** Research Student, RMIT University, Melbourne, Australia;

Email: luisacools1@gmail.com;

DOI: 10.16934/isr.18.1.201706.23 


\section{INTRODUCTION}

Safeguarding the livelihoods of a growing global population and ensuring sustainable models of growth and development are characterizing current international governance processes. The UN SDGs are the new and upgraded successors to the Millennium Development Goals (MDGs) and their focus is on offering a policy blueprint to address development in all its dimensions. While the MDGs focused on highlighting issues in global development related to poverty, they faced criticism for not offering implementable steps to achieve these goals, as well as not having a long-term future focus (Fehling et al. 2013; Mishra 2004; Oya et al. 2016). The SDGs by contrast have a central focus on "sustainability," not only in the environmental sense, but also in regards to responding to emerging development issues and ensuring that global development and policy reform is focused on longterm effectiveness (Kumar et al. 2016).

Reliance on ocean resources means that the complex and varied factors that drive human and environmental threats to marine ecosystems are crucial to the post-2015 development agenda. SDG 14: "Life Below Water" marks this global recognition of the importance of oceans for all life on earth and emphasizes the negative human impact in this ecosystem and the importance of oceans for sustaining human and ecological wellbeing. Assessing and managing the world's ocean activities is a large and multifaceted process. Negative impacts such as pollution, habitat destruction and climate change-related acidification are acting concurrently with overfishing and destructive fishing practices to degrade ocean ecosystems (Mañez et al. 2014; Charles 2012; Borja 2014). In order to protect them for the future and ensure more effective and streamlined management of ocean resources, more effective, holistic global governance is essential.

The focus of this article is on one important aspect of this global governance agenda: capture fisheries. SDG 14 is intended to shape the practices of global ocean activities, and while not all the related targets are focused on deep water fishing fleets, many of the targets can be applied to this particular aspect of ocean activities. Whether or not these aims are achieved will be vital for the overall SDG agenda and the future of governing and managing our oceans sustainably.

This article examines whether SDG 14 adequately addresses these issues and to what extent further governance action will be required. Section 2 outlines the importance of capture fisheries for global livelihoods from the economic, social and ecological perspective, such as contribution to the generation of wealth, employment and food security. Section 3 examines the current state of global of fisheries and how some practices and the management of these resources and industry inadequately secures sustainability for the future. Section 4 highlights what sustainability looks like in the global fishing industry, why it has been so difficult to achieve, the challenges of defining sustainability for fisheries, and the 
management of fisheries in the high seas and the Exclusive Economic Zones (EEZs) of developing countries. In defining sustainability for governance, Section 5 examines the oceans-related SDG 14 in more detail, and assesses whether it is adequate in addressing the issues surrounding capture fisheries and what it will take to achieve it. In conclusion, Section 6 addresses the need for effective governance of the oceans and whether further governance will be required beyond the SDGs to ensure the sustainability of "Life below Water" post-2015.

\section{ORIGIN OF THE SDGS AND THE TREND TOWARDS SUSTAINABILITY}

Addressing the issues related to the stand-alone oceans goal SDG 14 and the many complexities of human activities in the world's oceans is a major challenge. Addressing aspects of sustainability in these ocean activities renders the topic even more multidimensional.

Following three years of multi-stakeholder and intergovernmental negotiations, the SDGs represent the unprecedented coming together of two streams of global governance: the environment and development (Bexell and Jonsson 2016). What differentiates these goals from their predecessors is the focus on sustainability, diversifying partnerships for development, and the wide variety of issues they cover (Kumar et al. 2016). While the definition of sustainability is a widely debated topic dependent on industry and context, the simple explanation given by the World Commission on Environment and Development in 1987, is "development that meets the needs of the present without compromising the ability of future generations to meet their own needs" (Brundtland Commission 1987).

In developing the stand alone SDG 14, Small Island Developing States (SIDS) were important for championing the future of oceans, and perhaps most important for this goal were the related discussions by global leaders and a variety of stakeholders at the 2012 United Nations Conference on Sustainable Development (Rio+20) in Brazil (Keen et al. 2017; Quirk et al. 2016). These two streams of environment and governance merged in a significant way at this meeting. Governments agreed to set a number of SDGs to come into effect in 2015. According to the UNEP (2014), "these are broadly aimed at helping societies develop (in terms of health, education, food etc.) without compromising the environment."

This year (2017) marks the second year that the SDGs have been in place. In response to activating movement on SDG 14 and measuring current progress, the UN Ocean Conference will take place from June 5-9, 2017. Against the backdrop of upcoming world dialogues on the progress of SDG 14, such as the UN Ocean Conference, discussion on this goal and the issue of governance is imperative. 


\section{THE IMPORTANCE OF CAPTURE FISHERIES TO GLOBAL DEVELOPMENT AND LIVELIHOODS}

According to the FAO (2016), aquaculture now accounts for half of all the fish consumed around the world and is the fastest growing global food sector and production sector. In terms of sustainability, aquaculture has been heralded by some commentators as a means to meet the growing demand for seafood and resolve the unsustainability of global capture fisheries (Islam 2014; Lightfoot et al. 2016). Growth in this sector has compensated for the declines in quantity of fish available from capture fisheries (Garcia and Rosenberg 2010). Although it is worthwhile acknowledging the growing prominence of aquaculture industries around the world, capture fisheries maintain a more important case study for the discussion on SDG 14, sustainability and governance of resources.

Due to the nature of global capture fisheries and their historical, economic and political importance, it is essential to examine the adequacy of SDG 14 in providing a platform to address the sustainability issues of this specific industry. The large variety of stakeholders, as well as the importance to small scale artisanal fishers, renders capture fisheries a more complex and critical topic than aquaculture. Furthermore, there is a gap in the current aquaculture and fisheries literature that specifically addresses governance and sustainability issues, as independent to that of productive aquaculture (Jiang 2010; Cataudella et al. 2017). Most importantly, there are more complex governance and policy issues associated with the management of capture fisheries than with aquaculture, including the governance of the high seas, Illegal Unregulated and Unreported (IUU) fishing, disputed Exclusive Economic Zones (EEZs) and those of fishing capacity in developing countries, as well as greater difficulties in defining what sustainability looks likes in this industry.

From the economic perspective, fisheries contribute significantly to global and local economies. It is estimated that the direct value of outputs from capture fisheries worldwide amounts to US\$80-85 billion per year (FAO 2016). With the inclusion of processing and associated activities, the total contribution to global economic output rises to between US\$225 and US\$240 billion annually (Bene at al. 2016). The top three largest exporters of seafood in the world are China, Norway and Vietnam, with the trade of this resource worth US\$14.1 billion, US $\$ 8.8$ billion and US\$5.8 billion respectively (FAO 2016). For developing countries in the Global South, especially those with large coastal regions and the SIDSs, trade in seafood and fish accounts for a large proportion of economic income and Gross Domestic Product (GDP). It serves as an important source of revenue to service international debt, government services, and pay for food imports (Thilsted et al. 2016; Campling 2016). The contribution to the livelihood of developing countries is such that low-to-medium income countries supply half of all fish exports by value and more than $60 \%$ by quantity (FAO 2016). The economic contribution of capture fisheries and seafood 
exports to developing nations would be even greater if a number of barriers that hinder fish trade were removed - these include tariff and non-tariff measures, sanitary requirements, access to ports, regulations on foreign investment and other regulations on trade in fishing services (Bene et al. 2016, 177-196). In some Pacific Small Island Developing States (PSIDS), fisheries represent as much as $25 \%$ of GDP (Bene et al. 2016, 177-196). The importance to the economic and socioeconomic livelihood of these island nations is reflected in the fact that these countries were instrumental in campaigning for the inclusion of the stand-alone ocean goal (Keen et al. 2017; Quirk et al. 2016).

Capture fisheries are also a vital source of nutrition, food security and employment. Central to the discussions on sustainability and the post-2015 agenda is securing food sustainability and nutrition for a growing world population (Oldekop 2016). As highlighted in the 2016 UN Food and Agriculture Organization's (FAO) "State of the World's Fisheries Report" (FAO 2016), fish continue to be one of the most traded commodities in the world and recent reports by high-level experts, international organizations, industry and other non-profit groups highlight the tremendous potential of the world's oceans "to contribute significantly to food security and adequate nutrition for a global population expected to reach 9.7 billion by 2050." Capture fisheries and aquaculture provide more than 3 billion people with around $20 \%$ of their average intake of animal protein, and a further 1.3 billion people with about $15 \%$ (Bene et al. 2016). In some countries such as islands in the Indian and Pacific Oceans, the reliance on fish as a main source of protein is extremely high (Campling 2016). However, fish as a crucial source of nutrition is not limited to island nations. For example, $75 \%$ of dietary protein in Senegal and Sierra Leone comes from fish and makes up $63 \%$ of the animal protein that is consumed in total (IIED 2014).

Capture fisheries are also important in maintaining food supplies for livestock and aquaculture. These forage fish accounted for $37 \%$ of all fish taken from the oceans that year and were being used in feed for livestock such as pigs and chickens. However, $90 \%$ of this catch is turned into fish meal or fish oil and used as aquaculture feed (Herrero et al. 2015).

While there are a variety of studies supporting the importance of global fishing industries for addressing malnutrition and protein intake, new analysis has also indicated that the value of protein is also related to the type of fish that are available for people to consume (Belton et al. 2014). For example, in Bangladesh there is evidence that capture fisheries are faltering and the increase in aquaculture produce means that there is a far smaller variety of fish to choose from. As a result, people in Bangladesh are now eating 30\% more fish than two decades ago, but are getting fewer nutrients (Belton et al. 2014, 77-78; Bogard et al. 2015).

Inherently linked to socio-economic factors like nutrition and food security are other dimensions of global development—such as employment, gender rights 
and poverty alleviation. While it has been well established that capture fisheries are important resources for developing countries, there is little examination in the literature of the direct impact of the fishing industry on poverty reduction (Campling 2016). Against the backdrop of pursuing a sustainable post-2015 development agenda, it is also crucial to look at this industry through the lens of not only economic importance, trade and income, but also of top-down poverty reduction in developing nations. Fishing provides employment opportunities and contributes to people's livelihoods, and not only through nutrition (Golden et al. 2016; FAO 2016). Fisheries themselves are thought to directly employ more than 43.5 million people, with nearly 200 million working throughout the supply chain in associated processing, marketing, distribution and supply industries (IIED 2014). Related to the generation of employment, capture fisheries play a vital role in securing the livelihoods of women (Williams et al. 2002). The FAO (2014) highlights that gender discrimination in fisheries and aquaculture is rife. However, as Gupta et al. (2017) and Williams et al. (2002) highlight, there is a gap in genderfocused literature and unbiased gender data on the benefits to the livelihoods and rights of women in developing nations, as well as their roles in capture fisheries. Women make up the majority of the labor force in secondary activities along the supply-chain, such as fish processing and marketing. According to UN Women and the Asian Development Bank (ADB), this employment helps to safeguard gender rights and equality. In Sri Lanka, it was found that female participation in the fishing industry aided in the better management of financial services and distribution (ADB 2010).

While Mañez et al. (2014), Borja (2014) and others stress that human activity in the oceans has been proven to have had negative impacts, there is also an argument that, if managed effectively, capture fisheries and other ocean activities have a positive ecological impact on the ecosystem. Mizuta et al. (2017) highlight the potential effective use in global fisheries policy of the Japanese concept satoumi - which describes seascapes where human ecosystems have resulted in increased biodiversity and production, and thus have improved the health of the environment and ecosystem services. Darling et al. (2017) also highlight this human-ecosystem relationship as a way for assessing the impact and future of human activity in the oceans. The value of fish species to biodiversity in the oceans is also extremely hard to quantify and is one of the issues that needs to be addressed when using SDG 14 as a platform for developing a governance and policy framework.

\section{ASSESSING THE CURRENT STATE OF GLOBAL CAPTURE FISHERIES PRACTICES}

The value of global fisheries to global economies and livelihoods is clear, 
and it is therefore vital that the unsustainable practices that are characterizing the industry are remedied for the future. This section will assess the current state of global fisheries based on the current evidence and both sides of the debate. Analyzing current literature on capture fisheries practices that are unsustainable and those that are taking action to become a sustainable source of income, livelihood and employment will lay the foundation for assessing the adequacy of SDG 14 as a policy framework.

\section{History and Technological Advancement}

Technological advancement has contributed greatly to current practices in global capture fishing. It has had an impact on the way capture fisheries operate and increasing catch capacity. Fishing is one of the oldest endeavors of humankind, with fishing technology developing from simple nets and traps in lakes, rivers and coastal areas, to being carried out in all types of waters with a variety of sophisticated equipment (Purrington et al. 2017). With the first phases of industrial fishing carried out by steam trawlers, more recent innovations such as power winches, diesel engines, freeze trawlers, radar and acoustic fish finders have revolutionized the industry (Anticamara et al. 2011; Pauly et al. 2002). A massive surge in global fishing efforts, mainly by a small number of industrialized countries between 1950 and 1990, led to an increase in catches, which in turn encouraged capture fisheries managers and politicians to believe that increasing the size of fleets would automatically lead to higher catch sizes (Swartz et al. 2010).

Further technological advancement, such as Global Position Systems (GPS) and detailed maps of the sea floor have also allowed fishing boats to seek residual fish concentrations that have previously been sheltered in areas away from industrial fishing (Pauly et al. 2002). As the capacity for larger catches increased accordingly, fishers have begun to go deeper and to the untapped resources of West Africa, Southeast Asia and other low latitude regions in the Southern Hemisphere (Swartz et al. 2010).

Due to a lack of conscious management and in response to market demand and increased capacity, the combined engine power of the global high seas fleet has increased 10 times what it was in the 1950s (Bell et al. 2016). Government policies have also played a significant role in the increase in fishing catches. Global subsidies were estimated at US\$35 billion annually in 2009 , with capacity-enhancing subsidies accounting for US\$20 billion (Sumaila et al. 2016). Subsidies provided by developed countries (65\% of total) are far greater than those of developing countries, despite developing economies landing more than half of the annual global catch (Sumaila et al. 2016, 189; Thilsted et al. 2016). 


\section{Unsustainable Practices}

The impacts of the fishing industry on oceanic ecosystems is significant and complex. The direct impact of a larger catch capacity, increased demand, government subsidies and unconscious management has been a depletion of target species. According the FAO (2016), in 2013 almost 60\% of the assessed global fished stocks were "fully fished." Furthermore, $30 \%$ of the world's fish stocks are over exploited and more than half are fully exploited. Overfishing of the Pacific Bluefin Tuna (Thunnus Orientalis) is a prime example of the impact of current fishing practices. The population is reported to have dropped $96 \%$ as of 2013, with a very low probability of recovering according to the Scientific Committee of the RFMO in charge of their management as most of the specimens caught are young and have not reproduced (Harvey 2013). Only 1\% of stocks have a chance to recover from this state of depletion under current practices (IIED 2014).

In addition to the problem of fishing fleet capacity, other factors that have contributed to declining fish stocks include the deployment of damaging types of fish gear, such as derelict fishing gear and ghost fishing, which can result in the reduction in non-target species populations (including endangered species), as well as damaging marine habitats (UNEP 2014).

However, the views on the status of global fish stocks and fisheries management is polarized. A large part of the FAO's data on fish stocks comes directly from each country's fishing industry, which Gewin (2004) and other commentators argue is often biased as a result of unreported discarding, illegal fishing and misreporting harvests. While there is concern over this perceived gap in data, Angamuzi (2017) highlights the disagreement on the definition of "discards" and catches from country to country, while Spalding (2016) emphasizes that it is extremely difficult to quantify the economic and real values of oceans, adding to the ambiguity of definitions and data collection.

Another major impact current industrial fishing practices is the reduction of the trophic level of the world's oceans and the "fishing down" of marine food webs (see Pauly et al. 2002). The FAO (2016) and other recent studies (Komoroske and Lewison 2015) have highlighted the threat of fisheries bycatchthe incidental catch of unused and unmanaged species - on marine mega fauna and changing ocean trophic levels. Catches for most trophic levels are still rising, with some critics forecasting that this may contribute to fisheries collapse if not addressed quickly (Branch et al. 2010). While the threats to biodiversity do not arise from a single factor, it is also important to note the contribution of climate change (Worm et al. 2005; Anticamara and Go 2016), and the destructive impact that decades of relatively unchanged and unconscious fishing practices are having on fish stocks and the ocean environment. 


\section{Sustainable Policy and Management}

While there is a wide variety of evidence to support the claims of the unsustainability of current global fishing practices and depleting fish stocks, it is possible that this data does not account for current measures that are in place to sustainably manage these practices and introduce more sustainable management solutions (Murawski 2010; Bonanomi et al. 2017). Ye et al. (2016) undertook a large scale overview of current literature on global fish stocks and sustainability. They found that only $20 \%$ of current studies report on stable or recovering fish stocks, and most of the studies, whether reporting on stable or declining stocks, recommend some form of management structure for fisheries recovery and sustainability. At the forefront of the issue of sustainability in global fisheries is the management and governance of these ocean activities. As mentioned, there is an argument over the reliability of current data submitted by nation's pertaining to their fishing statistics (Worm et al. 2009; Angamuzi 2017).

There has been some success in rebuilding fish stocks to sustainable levels, but it has been relatively modest due to a lack of political will (Garcia and Rosenberg 2010; Murawski 2010; Gewin 2004). Glass et al. (2007) highlight that the perceptions and decisions of fishers themselves also affect the success of achieving sustainable use and management of global fish resources. The World Wildlife Foundation (WWF) works on encouraging collaboration with retailers and seafood companies to implement Fisheries Improvement Projects (FIPs), and participates in Fisheries Conservation Projects (FCPs) (Tolentino-Zondervan et al. 2016). Such collaborative and inclusive approaches rely on a high engagement with stakeholders. An example of an FIP that is focused on more sustainable fisheries management is Ecuador, where the WWF together with Ecuadorian government agencies assessed areas for improvement in the management of Mahi Mahi fishing, formal fishing strategies, more accurate fish stock data and the need for bycatch data (WWF 2017). Such programs that target the many facets of unsustainable fisheries practices and data management, as well as other data on replenishing and stable fish stocks, are encouraging and should not be overlooked. However, what such sustainability would look like in practice remains highly controversial, as discussed in the next section.

\section{MAKING FISHING SUSTAINABLE}

\section{What is Fisheries Sustainability?}

The management of sustainable fishing practices is extremely complex as there is a large number of stakeholders that are involved, each with differing priorities. There continues to be significant disagreement on defining sustainability 
in global fisheries. As mentioned in Section 2, the most widely used definition of broad sustainability comes from the Brundtland Commission (1987): "Sustainable development is development that meets the needs of the present without compromising the ability of future generations to meet their own needs." As "needs" and "compromising" are subject to interpretation, this definition is in fact quite ambiguous. Different stakeholders have therefore defined "sustainable seafood" according to different criteria according to their respective priorities (Tlusty and Thorsen 2016). As a result, a fish product may be considered sustainable by one stakeholder yet unsustainable by another (Hilborn et al. 2015). Much of the controversy over sustainability relates not to long-term yield potential of the resources but on the level and types of changes to the ecosystem that is considered acceptable. Sustainability in capture fisheries must drive economic, environmental and ethical process towards ensuring seafood availability meets the needs of the present without compromising the ability of future generations to meet their own needs (Tolentino-Zondervan et al. 2016).

The maximum sustainable fish catch was estimated to have been reached around 1990; however, what constitutes this is under debate (Gutierrez and Morgan 2015). In numerical terms it is hard to quantify sustainability of capture fisheries and what the targets might look like. While some fish stocks are in danger of depletion, they have varying recovery levels and without accurate data on a country-by-country basis, it is not viable to base future goals on reducing fishing pressure alone (Murawski 2010). Other measures, such as aiming to reduce bycatch and being aware of the danger of "tipping points" of a species where irreversible changes make take place are important features of changing fishing behavior from the bottom-up, in combination with policy changes (Hilborn et al. 2015). The modelling of a fishery in Southeast Australia suggests that more than $75 \%$ of the catch would need to be forgone in order to avoid overexploitation of any bycatch species. While some stakeholders would consider such lost food production acceptable, others that are concerned with the issue of food security may not (Hilborn et al. 2015; FAO 2016). In defining sustainability, the issue of waste produce is a serious consideration, and in particular in relation to capture fisheries, this issue of bycatch needs to be addressed in management practices pertaining to sustainability of the industry. A number of solutions that attempt to meet the expectations of all parties can be pursued including the introduction of vessel quotas on both stocks, the provision of individual incentives to fishermen (minimizing the catch of unproductive stocks), and attempts at equipment modification and innovation.

Hazen et al. (2016) and Tlusty and Thorsen (2016) emphasize that in order to define sustainability in fisheries for the future, there is a need not to simply focus on catch sizes and stock levels, but also to recognize that the ocean economy is changing, resulting in a sustainability dichotomy and the problem of communicating 
continual improvement in capture fisheries sustainability. Spalding (2016) further argues that before we are able to define sustainability in fisheries, we need establish agreement on the "new blue economy." This is an attempt "to create a unified, global definition of economic industries and activities that relate to the ocean in order to generate comprehensive and progressive economic health without violating other goals of sustainable development."

Ecosystem-based fisheries management is an important component of meeting these challenges. Ecosystem-based management for marine fisheries aims to reduce the potential impacts of fishing while allowing the extraction of fish resources at sustainable levels. While considerable progress has been made in ecosystem-based fisheries management, predicting the results of management actions remains challenging due to the complex, and poorly understood, dynamics of ecosystems. Also, significant gaps remain in the necessary information needed for such ecosystem-based management, with the identification and selection of appropriate objectives and indicators still problematic (Zhang et al. 2009). Despite these unresolved issues, Zhang et al. (2009: 37) persuasively argue that such efforts should proceed as "the potential benefits of implementation are as large as or greater than the potential risks of inaction." As fishery managers have more complete knowledge of the complex ecological and socio-economic environments involved in capture fishing, "they will be better able to anticipate the effects that fishery management will have on the ecosystem, as well as the effects that ecosystem change will have on fisheries" (Zhang et al. 2009: 37).

In particular, commercial fish populations and their associated ecosystems will be affected by changing environmental conditions even as fishing is ongoing. Fishing strategies must be evaluated within the context of these changing environmental conditions. The impact of climate change on ecosystem productivity, fish growth, recruitment, mortality, fish distribution, migration patterns, species composition, biodiversity, phenology, and input costs will all require careful, ecosystem-level management. Moreover, effects will vary according to changes in ocean conditions and sensitivity of the species, with each geographic region and environment facing its own special challenges. As such, new assessment approaches "are needed to project how climate change will affect marine ecosystems to alert policy-makers of the societal and ecological implications of climate change" (Zhang et al. 2011, 1318-1319).

\section{The Question of Management}

A consensus definition of sustainability in a fishery is only the first step. Effective management is required in order to enforce it (Hazen et al. 2016). Management is a process and not an end result. It must be both dynamic and responsive to change. At a minimum, there must be monitoring of ecosystem 
components and variations in productivity, with fishing pressures adjusted accordingly (Hilborn et al. 2015; Murawski 2010; Sherman et al. 2017). Effective sustainable fisheries have specific objectives and targets for fishing pressure and abundance. There must be monitoring of the level of fishing pressure and abundance of fish stocks, but without more dedication from country governments at collecting and analyzing this data of their own fish stocks, not much progress can be made (Sumaila et al. 2016). Assessments to determine if targets were being met must be fed-back into management systems so that regulations can be adjusted and fishing pressure restricted when necessary. Also, there needs to be enforcement to assure compliance with management regulations (Lubchenco et al. 2016).

There have been some national and intergovernmental attempts to implement more appropriate management practices, including the following: UN Marine Protection Areas (MPAs), which have had some successes at guiding fishing regulation and practices (O'Leary et al. 2016; Charles et al. 2016); applying a people and ecosystems approach to fisheries sustainability, which acknowledges ecological impact and resolves it with market demand (Mizuta et al. 2017; Darling et al. 2017); and implementing successful management policies as is occurring in some Latin American cases (Sherman et al. 2017). Subsidy structures in particular pose questions for the future management of global fisheries. In 2010, South Korea introduced a new framework for a Fisheries Management System (FMS) to the World Trade Organization (WTO) that stressed aspects such as data collection on catch sizes and fish stocks, and guidelines and prohibitions concerning overfished stocks (WTO 2011).

Reaching a consensus between major stakeholders and enforcing it through a management regime is difficult, but it has been achieved in certain cases. For example, the management of the salmon fishery in Alaska is regarded as among the best in the world (Hilborn et al. 2015). However, it has proved significantly more difficult for developing countries or in areas outside of the jurisdiction of any state - the high seas (Sumaila 2014). Both of these classes of fishing grounds are the sight of intense international competition. As the Global Ocean Commission (2014) notes, while "the international community has expended a tremendous amount of political capital and diplomatic effort on establishing policy commitments aimed at reversing ocean degradation...there remains a huge gap between the commitments expressed in various policy documents and the willingness or ability of States to implement them.”

\section{High Seas Governance}

Around $64 \%$ of the total surface area of the ocean is beyond the jurisdiction of any state (UNEP 2014). Inaccessibility had protected fish stocks in the high 
seas when the United Nations Convention on the Law of the Sea (UNCLOS) was being negotiated. This is no longer the case, and commercial fishing vessels can now fish anywhere (Global Ocean Commission 2014). Falling outside the jurisdiction of any state and without adequate governance, the high seas are experiencing overexploitation in a classic example of the problem known as the "tragedy of the commons" (Hardin 1968). As the Global Ocean Commission (2014) puts it: "The freedom is being exploited by those with the money and ability to do so, with little sense of responsibility or social justice." Hence there is a need for "a new UNCLOS implementing agreement to implement and update the environmental protection and conservation provisions of UNCLOS in the high seas" (Global Ocean Commission 2014). While there are some existing international instruments in charge of managing fishing activities outside of national jurisdiction, there is a need for a more effective legally binding instrument (Tsamenyi and Hanich 2012). This effective management of the high seas is not only intrinsically important, it also has a direct bearing on the ecological health and productivity of EEZs (UNEP 2014).

Fishing is important to the income and employment generation of many developing countries who depend on fish and seafood as their main resource (Campling 2016). Despite developing countries yielding most of the world's annual fish catch, developed countries account for the majority of global fisheries subsidies with Japan, China, the EU and the US are the highest subsidizers (Lam et al. 2015).

Fisheries subsidies have been under discussion within the World Trade Organization (WTO) for a considerable period of time. The WTO Doha Declaration of 2001 committed WTO members to "aim to clarify and improve WTO disciplines on fisheries subsidies, taking into account the importance of this sector to developing countries" (Global Ocean Commission 2014). Despite being obliged to report on specific subsidies, members do not all report on the details of fisheries subsidies (Aguado et al. 2016).

\section{Fishing in Developing Country EEZs}

Further issues arise in the pursuit of sustainable capture fisheries and the governance of maritime resources when ocean territory and governance are taken into account. The vast majority of fish-rich continental shelves are within the exclusive economic zones (EEZ) of maritime countries. This includes all coral reefs and their fisheries (Pauly et al. 2002). According to the 1982 United Nations Convention on the Law of the Sea, a country that cannot fully utilize the fisheries resource of its EEZ must make this surplus available to the fleets of other countries (Arias and Pressey 2016). This and the fact that the necessary effective compliance and enforcement of provisions is difficult for developing countries and 
SIDS in particular to achieve, along with eagerness for foreign exchange, political pressure and illegal fishing means that all of the world's shelves are fished industrially (UNEP 2014).

The problem of overfishing is further exacerbated by other issues. These problems are illegal, unreported and unregulated (IUU) fishing and destructive fishing practices (UNEP 2014). Global illegal, unregulated and unreported fishing is estimated to cost US\$9 to 24 billion annually. This represents between 11 and 26 million tons of fish or between 10 to $22 \%$ of total fisheries production (MRAG Asia Pacific 2016). Developing countries suffer the most from illegal fishing (MRAG Asia Pacific 2016; Agnew et al. 2009). Total estimated catches in West Africa are thought to be $40 \%$ higher than reported catches, which represents a significant loss in government revenue (landing fees, export earnings, taxes, etc.) (IIED 2014). However, governance of illegal fishing and the accountability measures to keep this in check are in short supply. Despite the existence of maritime governance conventions and laws, and cooperation between countries in shared EEZ areas, there is still a significant amount of governance failure and inadequacies in balancing fishing industry pressures with long-term sustainability.

\section{Achieving Sustainability Through Governance}

In order to achieve sustainability in global fisheries, management practices that have been successful in fisheries under the jurisdiction of a well-resourced and well governed state (such as the Alaskan salmon example above) need to be extended to the EEZs of developing countries and the high seas. According to (Pauly et al. 2002), if current trends are to be reversed, then a number of serious actions will need to be taken:

A huge reduction of fishing effort involving effective decommissioning of a large fraction of the world's fishing fleet will have to be implemented, along with fisheries regulations incorporating a strong form of the precautionary principle. The conceptual elements required for this are in place, for example, in form of the FAO Code of Conduct for Responsible Fisheries, but the required political will has been lacking so far, an absence that is becoming more glaring as increasing numbers of fisheries collapse throughout the world, and catches continue to decline. (p. 694)

Finding this political will has proven to be extremely difficult. Even within the mostly highly governed grouping of independent states in the world, the European Union, political will has been difficult to reach:

Although overexploitation of commercial fish stocks in European waters has 
been in the public debate now for more than 20 years, the European Union has so far failed to implement sustainable fisheries management. Millions in subsidies paid to the fishing industry have led to significant excess capacity in the fishing fleet. Various feeble attempts to stop overexploitation of marine resources have failed. The cause is that fishing policy is highly dominated by short-term socioeconomic interests (Hentrich and Salomon 2006, 712).

Bringing together the plethora of international and national governments involved to achieve sustainability is a daunting task (Global Ocean Commission 2014). If the Sustainable Development Goal Agenda is to be credible, Goal 14 will need to make a significant contribution to addressing the issue of sustainable governance of global capture fisheries. This is the issue we turn to next, starting with the process that led to the Global Goal for the Oceans.

\section{MAKING PROGRESS TOWARD GOAL 14: CONSERVE AND SUSTAINABLY USE THE OCEANS, SEAS AND MARINE RESOURCES FOR SUSTAINABLE DEVELOPMENT}

As noted above, the SDGs represent the coming together of two streams of global governance: the environment and development. For the most part, Goal 14 and its sub-goals and targets that emerged out of this process are not novel. So their utility comes down to the extent to which they are able to mobilize new progress. As Parmentier (2015) observed, "Veterans of the ocean conservation community may say that the majority of these targets sound familiar, almost like a broken record." He also points out that legally-binding commitments signed in the past did not necessarily result in change. However, for Parmentier (2015), the contribution of SDG 14 is the potential to make ocean recovery central to sustainable development. The high profile of the SDGs will also hopefully contribute to increased accountability for ocean-related policies. The UN Ocean conferences to be held every three years (from 2017 to 2029) will play a role in this monitoring and review process. The first of these conferences is to be held 5 to 9 June 2017 (United Nations General Assembly 2016). In the past, this kind of UN-led monitoring and review process and associated additional governmental and non-governmental monitoring and activism have had mixed results (UN Department of Economic \& Social Affairs 2015).

It is still too early in the process to make an assessment on Goal 14's contribution to accountability to fisheries governance. However, it is possible to discuss areas of improvement in the goal's text itself. Below we address each of the fishing-related sub-goals in turn. 
avoid significant adverse impacts, including by strengthening their resilience, and take action for their restoration in order to achieve healthy and productive oceans

Put simply, if this sub-goal is not met then Goal 14 will not be achieved. Along with 14.1 and 14.4, the International Council for Science (ICSU 2015) identifies this sub-goal as "most important for this goal." The ICSU also states that these sub-goals have "the strongest science base," meaning that we will have a clear indication of progress. However, the UNEP (2014) does not see this sub-goal as "actionable" as it is "too vague to assess" with "many aspects open to interpretation." The UNEP also criticizes the lack of targets and a baseline. This issue of measurable targets and baselines is crucial. "Adverse impacts," "healthily" and "productive" relate directly to what level of changes to the ecosystem are considered acceptable (see above). For this sub-goal to be comprehensible, let alone achievable, these terms must be defined and then assigned a baseline and a target.

\subsection{By 2020, effectively regulate harvesting and end overfishing, illegal, unreported} and unregulated fishing and destructive fishing practices and implement sciencebased management plans, in order to restore fish stocks in the shortest time feasible, at least to levels that can produce maximum sustainable yield as determined by their biological characteristics

Effectively regulating and end to overfishing and destructive practices is the key to sustainability, but it requires agreement on what that means and putting the resources in place to enforce that agreement. The UNEP (2014) is more optimistic about this sub-goal, describing it as actionable "if there is political will and resources available." According to the UNEP, measuring progress and regulating harvesting is feasible. However, other aspects such as IUU are difficult to measure and are not feasible. So in the overall view of the UNEP, some aspects are achievable and some are not. Reduction in IUU is possible with more rigorous enforcement, so it appears that the UNEP is assessing the level of political will to be lacking. A further problem with this sub-goal is that it does not address the key issue of species that do not produce a yield (i.e. bycatch).

14.5 By 2020, conserve at least 10 percent of coastal and marine areas, consistent with national and international law and based on the best available scientific information

The major flaw with this sub-goal is that the meaning of "conserve" and "coastal and marine areas" are not defined. As the UNEP (2014) points out, the $10 \%$ of spatial extent is measurable but meaningless if it is not effectively managed and monitored. Also, setting aside less significant areas will have much less impact than richer habitats such as reefs. This sub-goal would be significantly stronger is there were clearly defined targets. Finally, these targets would ideally be country targets: if $10 \%$ of each EEZ and $10 \%$ of the high seas were effectively 
managed for sustainability it would be a significant improvement.

14.6 By 2020, prohibit certain forms of fisheries subsidies which contribute to overcapacity and overfishing, eliminate subsidies that contribute to illegal, unreported and unregulated fishing and refrain from introducing new such subsidies, recognizing that appropriate and effective special and differential treatment for developing and least developed countries should be an integral part of the World Trade Organization fisheries subsidies negotiation

To be successful, this sub-goal requires transparency and enforcement. Compared to other sub-goals, this sub-goal has the advantage that the WTO already provides an unusually high level of transparency and enforcement, at least by international standards (see for example Mitchell and Sheargold 2009). Accordingly, the UNEP (2014) describes this sub-goal as actionable, measurable, and achievable, with the caveat that it requires "WTO members [to] want it to happen" and "political will." The International Council for Science (ICSU 2015) argues that the wording should be stronger and "prohibit all subsidies that contribute to overcapacity and overfishing." It also sees the WTO as only one mechanism available for monitoring and enforcement. This scepticism of the WTO is warranted, as its history of enforcement is decidedly mixed (Mitchell and Sheargold 2009). So one important forum where change will need to occur is the WTO.

In this regard The Global Ocean Commission (2014) argues that existing WTO obligations related to subsidies should be enforced, and that members should disclose to the organization, and to each other, "the type and scope of subsidies that they provide to the fisheries sector." The commission also suggests that fisheries subsidies must be clarified in order to identify and distinguish those that are harmful.

\subsection{By 2030, increase the economic benefits to Small Island developing States} and least developed countries from the sustainable use of marine resources, including through sustainable management of fisheries, aquaculture and tourism

This goal has the potential to be extremely significant. If the Small Island Developing States and least developed countries are able to benefit more from their marine resources it will provide a strong incentive to manage these resources sustainably. The UNEP (2014) approaches this through the traditional development paradigm, suggesting major development aid financing or "innovative finance." It criticizes the lack of a target or indicator to measure, stating that it is even difficult to define a meaningful one. So in the view of the UNEP, this sub-goal is only feasible in specific areas/fisheries and is "highly unlikely" to be achieved "globally for some time." However, this pessimism is somewhat misplaced. Funds from the donor and finance community are not strictly necessary, as the value of fish catches by foreign fleets are often much higher than ODA received (Petersen 2003). For example, the Members of the Parties to the Nauru Agreement (PNA) aim to essentially establish 
an "OPEC of Tuna" to increase their bargaining power vis-a-vis the major distant water fishing nations (e.g. PNA 2010). This effort has received considerable pushback from the major distant water fishing nations operating in the PNA area, many of whom are also major donors. The inclusion of this sub-goal could help in increasing the bargaining power of LDCs to work cooperatively to increase the fees and other costs imposed on distant water fishing nations.

\section{4.b Provide access for small-scale artisanal fishers to marine resources and markets}

A major limitation of this sub-goal is that it requires greater political will on the part of both distant water fishing nations and the host states. Many host states are more interested in having DWFNs process catches onshore than extending the property rights of artisanal fishers (Barclay 2010). So while in the view of the UNEP it is actionable and feasible, it is not achievable globally for "a long time." A perhaps an even more pressing issue that the UNEP does not address is the need to exclude DWFN vessels from waters where artisanal or small-scale local fishers operate (see for example Gagern and van den Bergh 2013).

14.c Enhance the conservation and sustainable use of oceans and their resources by implementing international law as reflected in UNCLOS, which provides the legal framework for the conservation and sustainable use of oceans and their resources, as recalled in paragraph 158 of The Future We Want (UN 2016)

The UNEP (2014) categorizes this sub-goal as actionable, possibly measurable (with "some consensus building") and feasible on a regional level. "Areas Beyond National Jurisdiction (ABNJ)" are "much more of a challenge." So overall, it is achievable for "for selected geographic areas in the medium term, globally very long-term except for ABNJ where it is not certain." UNCLOS provides the legal justification for enforcement by host states. Implementation is a matter of will and resources. The latter is addressed in sub-goal 14.7. However, UNCLOS does not obligate DWFNs to compel their own nationals to abide by the lawful rights of host states or areas outside national jurisdiction. Clearly, UNCLOS is an incomplete mechanism and SDG 14 missed an opportunity to strengthen the legal framework.

\section{Goal 14 and Governing Sustainability in Distant Water Capture Fisheries}

Like much criticism surrounding the new SDGs and also the MDGs before them, a wide array of stakeholders have questioned whether the standalone goal on oceans provides an adequate roadmap to ensuring sustainable practices related to the management of ocean resources and capture fisheries. Judging whether Goal 14 is adequate to address the wide range of issues that surround capture fisheries can first be tackled by determining whether the targets align with, and directly 
address, some of the most significant unsustainable trends in this industry. With a rise in market demand and technological innovation resulting in increased capacity for larger catches, capture fishing combined with other factors is having an impact on the population of target species. These impacts also include the following: the reduction of trophic levels of the world's oceans; the threat of extinction of entire species due to IUU overfishing; the depletion of certain population locations; a rise in government subsidies that threaten local artisan fisheries and small industries in developing nations; and a spike in global fish prices and seafood scarcity-resulting in higher demand, increased competition between countries and governance over ocean territory.

While not all of the targets under Goal 14 directly address unsustainability in capture fisheries, the remaining targets are also impacted to some extent by practices in this industry. Addressing the acidity of the ocean environment under target 14.3 will aid the plight of fish species not only threatened by overfishing and climate-change, and also address the sum of many factors that are acting on the ocean ecosystem. Target 14.4 directly addresses the many issues associated with illegal, unreported and unregulated overfishing with attempts to restore fish stocks and implemented science-based policy making. Addressing the damage that has already been done has become an important theme linked with Goal 14 and wider notions of sustainability. With more than $50 \%$ of the world's fish stocks already depleted (World Ocean Review 2015), the recovery of these populations in the short timeframe expressed under target 14.4 will be a challenge. With the majority of the most productive fisheries catches residing within the coastal shelves enclosed within EEZs, the ambitions of target 14.5 to conserve a greater percentage of the world's coastal areas and ecosystems needs to be better outlined. Additionally, while the inclusion of the target specifically dedicated to reducing and prohibiting certain fisheries subsidies (Target 14.6) is needed, like the many conventions governing ocean laws, whether these subsidies are actually implemented at the policy level remains to be seen. In acknowledging the importance of capture fisheries to the economies and livelihoods of many developing and island nations, the most implementable target is 14.7 , which aims to increase the economic benefits of global fisheries for developing nations. However, the action on this target will be, and has already been, mainly on the part of the states concerned, rather than a collective approach by all states and stakeholders.

Cooperation between a number of states that depend mainly on ocean resources and fisheries are at the forefront. The Indian Ocean Rim Association and cooperation between Mauritius, Sweden, the Netherlands and Samoa have highlighted increasing economic benefits sustained from the fisheries industry as a main priority in achieving Goal 14 (IIED 2016). For example, the Ministry of Agriculture and Fisheries (MAF) of Samoa has stressed the importance of effective governance and policy in addressing the unsustainable and exploitative 
practices of the capture fishing industry. Some solutions they are pursuing include introducing more sustainable equipment and fishing techniques, as well as introducing vessels that operate more economically and with less environmental impact (MAF 2016). Additionally, target 14b appropriately addresses the need to improve market access for small artisanal fishers, who are increasingly being pushed out by the large scale industrial capture fisheries industry and by fleets of increasing sizes and capacity.

The global SDGs - and in particular Goal 14 - only provide a portion of the targeted and accountable governance that is needed to address the issues associated with unsustainable capture fisheries. Target $14 \mathrm{c}$ stresses the full implementation of international maritime conventions, but despite conventions such as these, illegal and unregulated fishing is still a concern. Additionally, the targets directly associated to capture fisheries are not detailed enough to address all aspects and factors of the unsustainable practices that persist in this industry. A refinement of the targets of Goal 14 as well as a concerted effort by participating stakeholders and governments to cooperate on actionable solutions to these issues will be needed.

\section{CONCLUSION}

The oceans are critically important to the overall success of the post-2015 sustainable development agenda. As the first global goal dedicated to the preservation of ocean resources that has collectively been agreed upon by the world, in a very real sense, the most important role that the goal is playing is to focus attention on the issue of unsustainable fisheries. Despite the knowledge of the importance of marine resources to the livelihoods of a large number of countries around the world in terms of employment, income generation, and gender equality, current practices in the industry make it unsustainable. Increases in market demand and increased capacity resulting from technological innovation has resulted in overfishing and depletion of ocean resources. Much like other policies for global development, the post-2015 development agenda is being increasingly characterised by evidence-based decision making, to account for the many different priorities of a range of stakeholders in issues related to global sustainability. To be successful, the attention this goal has placed on ocean resources will need to translate into the political will to improve governance of global fisheries and reduce catches. Or as the UNEP (2014) puts it, improve the "interface between science and decision-making." This need is directed not only towards national governments and policy implementation, but changes in the practices of all stakeholders that are involved in this diverse industry. It remains to be seen whether the increased focus provided by Goal 14 will translate into an effective sustainability regime for global fisheries. Cooperation among all stakeholders and increased partnerships aimed at tackling these issues of sustainability will be vital. 


\section{REFERENCES}

ADB. 2010. "Gender Equality Results: Case Studies, Sri Lanka," accessed May 12, 2016, http://www.adb.org/sites/default/files/publication/28746/gender-casestudy-sri.pdf

Aguado, S. Hernandez, I. Segado Segado, and Tony J. Pitcher. 2016. "Towards Sustainable Fisheries: A Multi-Criteria Participatory Approach to Assessing Indicators of Sustainable Fishing Communities: A Case Study from Cartagena (Spain)." Marine Policy 65: 97-106.

Agnew, D. J., J. Pearce, G. Pramod, T. Peatman, R. Watson, J. R. Beddington, and T. J. Pitcher. 2009. "Estimating the Worldwide Extent of Illegal Fishing." PLoS ONE 4(2): e4570, https://doi.org/10.1371/journal.pone.0004570

Anticamara, J. A., R. Watson, A. Gelchu and D. Pauly. 2011. "Global Fishing Effort (1950-2010): Trends, Gaps, and Implications.” Fisheries Research 107(1): 131-136.

Anticamara, Jonathan and Kevin Thomas B. Go. 2016. "Spatio-Temporal Declines in Philippine Fisheries and its Implications to Coastal Municipal Fishers' Catch and Income." Frontiers in Marine Science 3(21), doi:10.3389/fmars. 2016.00021 .

Arias, A. and R. L. Pressey. 2016. "Combatting Illegal, Unreported, and Unregulated Fishing with Information: A Case of Probable Illegal Fishing in the Tropical Eastern Pacific.” Frontiers in Marine Science 3(13), doi:10.3389/fmars.2016. 00013.

Barclay, Kate. 2010. "Impacts of Tuna Industries on Coastal Communities in Pacific Island Countries.” Marine Policy 34(3): 406-413, https://doi.org/10.1016/j.marpol. 2009.09.003

Bell, Justin D., Reg A. Watson and Yimin Ye. 2016. "Global Fishing Capacity and Fishing Effort from 1950 to 2012." Fish and Fisheries 18(3): 489505, doi:10.1111/faf.12187.

Belton, Ben, van Asseldonk, Imke Josepha Mariana and Shakuntala Haraksingh Thilsted. 2014. "Faltering Fisheries and Ascendant Aquaculture: Implications for Food and Nutrition Security in Bangladesh." Food Policy 44: 77-87. http://www.sciencedirect.com/science/article/pii/S0306919213001632

Béné, Christophe, Robert Arthur, Hannah Norbury, Edward H. Allison, Malcolm Beveridge, Simon Bush, Liam Campling, Will Leschen, David Little, Dale Squires, Shakuntala H. Thilsted, Max Troell, and Meryl Williams. 2016. "Contribution of Fisheries and Aquaculture to Food Security and Poverty Reduction: Assessing the Current Evidence." World Development 79: 177196, doi: http://dx.doi.org/10.1016/j.worlddev.2015.11.007

Bexell, Magdalena and Kristina Jonsson. 2016. "Responsibility and the United Nations Sustainable Development Goals." Forum for Development Studies 
44(1): 13-29, http://www.tandfonline.com/doi/full/10.1080/08039410.2016. 1252424

Bogart, Jessica R, Shakuntala H. Thilsted, Geoffrey C. Marks, Md. Abdul Whab, Mostafa A. R. Hossain, Jette Jakobsen and James Stangoulis. 2015. "Nutrient Composition of Important Fish Species in Bangladesh and Potential Contribution to Recommended Nutrient Intakes." Journal of Food Composition and Analysis 42 (September): 120-133.

Bonanomi, Sara, Alessandro Colombelli, Loretta Malvarosa, Maria Cozzolino and Antonello Sala. 2017. "Towards the Introduction of Sustainable Fishing Products: The bid of a Major Italian Retailer." Sustainability 9(3): 438, http://www.mdpi. com/2071-1050/9/3/438/htm

Borja, A. 2014. "Grand Challenges in Marine Ecosystems Ecology." Frontiers in Marine Science 1(1): doi: 10.3389/fmars.2014.00001.

Branch, T. A., R. Watson, E. A. Fulton, S. Jennings, C. R. McGilliard, and G. T. Pablico. 2010. "The Trophic Fingerprint of Marine Fisheries.” Nature 468: 431-435. doi: 10.1038/nature09528.

Brundtland Commission. 1987. Our Common Future: Report of the World Commission on Environment and Development, Chapter 2: Towards Sustainable Development (A/42/427). October. New York: United Nations. http://www.undocuments.net/ocf-02.htm

Campling, Liam. 2016, September 23. The Global Value Chain in Canned Tuna, The International Trade Regime and Implementation of Sustainable Development Goal 14 (International Trade Working Paper N²016/22). doi:10.14217/24133175.

Cataudella, Stefano Massa, and Fabio and Donatella Crosetti. 2017. Thematic Lectures: Interactions between Capture Fisheries and Aquaculture. Rome: Fisheries and Aquaculture Department, Food and Agriculture Organization of the United Nations, http://www.fao.org/docrep/009/a0141e/A0141E05.htm

Charles, Anthony. 2012. "People, Oceans and Scale: Governance, Livelihoods and Climate Change Adaptation in Marine Socio-ecological Systems." Current Opinion in Environmental Sustainability 4(3): 351-357,

http://www.sciencedirect.com/science/article/pii/S1877343512000668

Charles, Anthony, Devin M. Bartley, Warrick J. Flectcher, Serge Garcia, Hugh Govan, and Jessica Sanders 2016. "Fishing Livelihoods as Key to Marine Protected Areas: Insights from the World Parks Congress." Aquatic Conservation: Marine and Freshwater Ecosystems 26(2): 165-184.

Darling, Emily S. and Stephanie D'agata. 2017. "Coral Reefs: Fishing for Sustainability." Current Biology 27(2): 65-68, doi: https://doi.org/10.1016/j.cub. 2016.12.005

FAO. 2014. "The State of World Fisheries and Aquaculture 2014: Opportunities and Challenges." Rome. 221 pp. 
FAO. 2016. "The State of World Fisheries and Aquaculture 2016: Contributing to Food Security and Nutrition for All." Rome. 200 pp.

Fehling, Maya, Brett D. Nelson and Sridhar Venkatapuram. 2013. "Limitations of the Millennium Development Goals: A literature Review." Global Public Health 8(10): 1109-1122, https://www.ncbi.nlm.nih.gov/pmc/articles/PMC $\underline{3877943 /}$

Gagern, Antonius and Jeroen van den Bergh. 2013. "A Critical Review of Rishing Agreements with Tropical Developing Countries.” Marine Policy 38 (March): 375-386, http://doi.org.ssl.access.yonsei.ac.kr:8080/10.1016/j.marpol.2012.06. $\underline{016}$

Garcia, Serge M. and Andrew A. Rosenberg. 2010. "Food Security and Marine Capture Fisheries." Philosophical Transactions of the Royal Society B: Biological Sciences 365(1554): 2869-2880, http://doi.org/10.1098/rstb.2010. $\underline{0171}$

Gewin, V. 2004. "Troubled Waters: The Future of Global Fisheries." PLoS Biol 2(4): e113, https://doi.org/10.1371/journal.pbio.0020113

Glass, Christopher W., Stephen J. Walsh and Bob van Marlen. 2007. "Fishing Technology in the 21st Century: Integrating Fishing and Ecosystem Conservation." ICES J Mar Sci 64(8): 1499-1502. doi: 10.1093/icesjms/fsm139, https://academic.oup.com/icesjms/article/64/8/1499/613997/Fishing-technologyin-the-21st-century-integrating

Global Ocean Commission. 2014. From Decline to Recovery: A Rescue Package for the Global Ocean (Report Summary). Oxford, UK: Global Ocean Commission. Golden, C., E. H. Allison, W. W. Cheung, M. M. Dey, B. S. Halpern, D. J. McCauley, M. Smith, B. Vaitla, D. Zeller and S. S. Myers. 2016. "Fall in Fish Catch Threatens Human Health." Nature 534(7607): 317-320.

Gupta, Joyeeta, Dilanthi Koralagama and Nicky Pouw. 2017. "Inclusive Development from a Gender Perspective in Small Scale Fisheries." Current Opinions in Environmental Sustainability 41(1): 1-6.

Gutiérrez, A. T. and S. K. Morgan. 2015. "The Influence of the Sustainable Seafood Movement in the US and UK Capture Fisheries Supply Chain and Fisheries Governance." Frontiers in Marine Science 2:72. doi: 10.3389/fmars. 2015.00072, http://journal.frontiersin.org/article/10.3389/fmars.2015.00072/full Hardin, G., 1968. "The Tragedy of the Commons." Science 162(3859): 1243-1248. Harvey, Fiona. 2013. "Overdishing Causes Pacific Bluefin Tuna Numbers to Drop 96\%." The Guardian (online). January 9, 2013, accessed May 12, 2016, http://www.theguardian.com/environment/2013/jan/09/overfishing-pacificbluefin-tuna

Hazen, Lucie, Eodie Le Cornu, Amanda Zerbie, Rebecca Martone, Ashley L. Erickson and Larry B. Crowder. 2016. "Translating Sustainable Seafood Frameworks to Assess the Implementation of Ecosystem-based Fisheries 
Management." Fisheries Research 182: 149-157.

Hentrich, Steffen and Markus Salomon. 2006. "Flexible Management of Fishing Rights and a Sustainable Fisheries Industry in Europe." Marine Policy 30(6):

712-720, doi: http://dx.doi.org/10.1016/j.marpol.2005.11.003

Herrero, Mario, Stefan Wirsenius, Benjamin Henderson, Cyrille Rigolot, Philip Thornton, Petr Havlik, Imke de Boer and Peirre J. Gerber. 2015. "Livestock and the Environment: What Have We Learned in the Past Decade?" Annual Review of Environment and Resources 40: 177-202, http://www.annualreviews.org/ doi/full/10.1146/annurev-environ-031113-093503\# i2

Hilborn, Ray, Elizabeth A. Fulton, Bridget S. Green, Klaas Hartmann, Sean R. Tracey, and Reg A. Watson. 2015. "When is a Fishery Sustainable?" Canadian Journal of Fisheries and Aquatic Sciences 72 (9): 1433-1441. doi: 10.1139/cjfas2015-0062.

ICSU. 2015. Review of Targets for the Sustainable Development Goals: The Science Perspective. Paris: International Council for Science (ICSU).

Islam, M. D. Saidul. 2014. Confronting the Blue Revolution: Industrial Aquaculture and Sustainability in the Global South. Toronto: University of Toronto Press.

Jiang, Shan. 2010. "Aquaculture, Capture Fisheries and Wild Fish Stocks." Resource and Energy Economics 32(1): 65-77, http://www.sciencedirect.com/ science/article/pii/S0928765509000347

Keen, Meg R., Anne-Maree Schwarz and Lysa Wini-Simeon. 2017. "Towards Defining the Blue Economy: Practical Lessons from Pacific Ocean Governance." Marine Policy, accessed March 9, 2017, http://www.sciencedirect.com/science/ article/pii/S0308597X16308235

Komoroske, L. M. and R. L. Lewison. 2015. "Addressing Fisheries by Catch in a Changing World." Frontiers of Marine Science 2: 83. doi: 10.3389/fmars.2015. 00083 http://journal.frontiersin.org/article/10.3389/fmars.2015.00083/full

Kumar, Sanjiv, Neeta Kumar and Saxena Vivekadhish. 2016. "Millennium Development Goals (MDGs) to Sustainable Development Goals (SDGs): Addressing Unfished Agendas and Strengthening Sustainable Development and Partnerships." Indian Journal of Community Medicine 41(1): 1-4, https://www.ncbi.nlm.nih. gov/pmc/articles/PMC4746946/

Lam, Vicky, Frederic Le Manach and Daniel Pauly. 2015. "Global Fisheries Subsidies: An Updated Estimate.” Marine Policy 69(July): 189 -193.

Lightfoot, Clive, Mary Ann P. Bimbao, Jens Peter T. Dalsgaard and Roger S.V. Pullin. 2016. "Aquaculture and Sustainability through Integrated Resources Management." Outlook on Agriculture 22(3): 143-150, http://journals.sagepub. com/doi/abs/10.1177/003072709302200303

Lubchenco, Jane, Elizabeth B. Cerny-Chipman, Jessica N. Reimer and Simon A. Levin, 2016. "The Right Incentives Enable Ocean Sustainability Successes and Provide Hope for the Future." PNAS 113(51): 14507-14514; published 
ahead of print December 2, 2016, doi:10.1073/pnas.1604982113.

MAF. 2016. "Farming and Fishing First." Ministry of Agriculture and Fisheries Samoa. Accessed May 12, 2016, http://www.maf.gov.ws/index.php/fisheries/ development

Máñez, Schwerdtner K., P. Holm, L. Blight, M. Coll, A. MacDiarmid, H. Ojaveer, B. Poulsen, and M. Tull. 2014. "The Future of the Oceans Past: Towards a Global Marine Historical Research Initiative." PLoS ONE 9(7): e101466, https://doi.org/10.1371/journal.pone.0101466

Mishra, U. S. 2004. "Millennium Development Goals: Whose Goals and for Whom?" British Medical Journal 329(7468): 742. doi:10.1136/bmj.329.7468. 742-b.

Mitchell, Andrew D. and Elizabeth Sheargold. 2009. "Global Governance: The World Trade Organization's Contribution.” Alberta Law Review 46(4): 10611080.

Mizuta, Darien and Eirini Ioanna Vlachopouloub. 2017. "Satoumi Concept Illustrated by Sustainable Bottom-up Initiatives of Japanese Fisheries Cooperative Associations." Marine Policy 78: 143-149.

MRAG Asia Pacific. 2016. Towards the Quantification of Illegal, Unreported and Unregulated (IUU) Fishing in the Pacific Islands Region. Toowong, Australia: MRAG Asia Pacific, http://www.ffa.int/files/FFA\%20Quantifying\% 20IUU\%20Report\%20-\%20Final.pdf

Murawski, Steven A. 2010. "Rebuilding Depleted Fish Stocks: The Good, the Bad, and, Mostly the Ugly." ICES Journal of Marine Sciences 67: 18301840.

Oldekop, J. A., L. B. Fontana and J. Grugel. 2016. "100 Key Research Questions for the Post-2015 Development Agenda." Development Policy Review 34: 55-82. doi:10.1111/dpr.12147.

O’Leary, C. Bethan, Marit Winther-Janson, and John M. Bainbridge. 2016. "Effective Coverage Targets for Ocean Protection." Conservation Letters 9(6): 398-404.

Oya, C. 2011. "Africa and the Millennium Development Goals (MDGs): What's Right, What's Wrong and What's Missing." Revista De Economia Mundial 27: 19-33, http://www.sem-wes.or

Parmentier, Rémi 2015. "SDG at Sea" (Guest Article \#42). New York, NY: International Institute for Sustainable Development.

Pauly, Daniel, Villy Christensen, Sylvie Gunette, Tony J. Pitcher, U Rashid Sumaila, Carl J. Walters, R. Watson, R. and Dirk Zeller. 2002. "Towards Sustainability in World Fisheries." Nature 418: 689-695.

Petersen, Elizabeth. 2003. "The Catch in Trading Fishing Access for Foreign Aid." Marine Policy 27(3): 219-228, https://doi.org/10.1016/S0308-597X(02)00059-3

PNA. 2010, February 25. PNA Presidents Meet to Decide Way Forward for Tuna. 
Majuro, Marshall Islands: Parties to the Nauru Agreement (PNA), http://www. pnatuna.com/node/108

Purrington, Philip F., John C. Sainsbury, Georg A. Borgstrom, Dag Pike, Clyde H. Amundson and Andres R.F.T. von Brandt. 2017, March 31. "Commercial Fishing" in Encyclopcedia Britannica, https://www.britannica.com/technology/ commercial-fishing

Quirk, Genevieve and Quentin Hanich. 2016. "Ocean Diplomacy: The Pacific Island Countries Campaign for an Ocean Sustainable Development Goal." Asia-Pacific Journal of Ocean Law and Policy 1: 68-95, doi: https://doi.org/ $\underline{10.1163 / 24519391-00101005}$

Sherman, Kenneth, Norma Patricia Muñoz Sevilla, Porfirio Álvarez Torres and Betsy Peterson. 2017. "Sustainable Development of Latin American and the Caribbean Large Marine Ecosystems." Environmental Development, accessed April 8, 2017, https://doi.org/10.1016/j.envdev.2017.04.001

Spalding, Mark J. 2016. "The New Blue Economy: The Future of Sustainability." Journal of Ocean and Coastal Economics 2(2): Article 8.

Sumaila, U Rashid, Vicky Lam, Dana D. Miller, Louise Teh, Reg A. Watson, Dirk Zeller, William W. L. Cheung, Isabelle M. Côté, Alex D. Rogers, Callum Roberts, Enric Sala, and Daniel Pauly. 2014. "Winners and Losers in a World Where High Seas are Closed to Fishing." Scientific Reports 5: 8481, https://www.nature.com/articles/srep08481

Sumaila, U Rashid, Christophe Bellman and Alice Tipping. 2016. "Fishing for the Future: An Overview of Challenges and Opportunities." Marine Policy 69(July): 173-180.

Sumaila, U Rashid, Vicky Lam, Frederic Le Manach, Wilf Swartz and Daniel Pauly. 2016. "Global Fisheries Subsidies: An Updated Estimate." Marine Policy 69: 189-193, http://www.sciencedirect.com/science/article/pii/S0308597 $\underline{X 16000026}$

Swartz, W., E. Sala, S. Tracey, R. Watson and D. Pauly. 2010. "The Spatial Expansion and Ecological Footprint of Fisheries (1950 to present)." PloS one 5(12): e15143.

Tsamenyi, Martin and Quentin Hanich. 2012. "Fisheries Jurisdiction under the Law of the Sea Convention: Rights and Obligations in Maritime Zones under the Sovereignty of Coastal States." International Journal of Maritime and Coastal Law 27(4): 783-793.

Thilsted, Shakuntala Haraksingh, Andrew Thorne-Lyman, Patrick Webb, Jessica Rose Bogard, Rohana Subasinghe, Michael John Phillips, and Edward Hugh Allison. 2016. "Sustaining Healthy Diets: The Role of Capture Fisheries and Aquaculture for Improving Nutrition in the post2015 Era." Food Policy 61: 126-131.

Tlusty, Michael and Oisten Thorsen. 2016. "Claiming Seafood is 'Sustainable' 
Risks Limiting Improvements." Fish and Fisheries 18: 340-346, doi:10.1111/ faf.12170DOI: 10.1111/faf.12170.

Tolentino-Zondervan, F., P. Berentsen, S. R. Bush, L. Digal and A. Oude Lansink. 2016. "Fisher-Level Decision Making to Participate in Fisheries Improvement Projects (FIPs) for Yellowfin Tuna in the Philippines." PLoS ONE 11(10): e0163537. https://doi.org/10.1371/journal.pone.0163537, http://journals.plos. org/plosone/article?id=10.1371/journal.pone.0163537

Williams, M. J., S. B. Williams and P. S. Choo. 2002. "Global Symposium on Women in Fisheries: Sixth Asian Fisheries Forum." 29 November 2001, Kaohsiung, Taiwan, https://www.worldfishcenter.org/content/women-fisheriesgender-and-fisheries

World Ocean Review. 2015. The State of Fisheries Worldwide. Report. Accessed May 12, 2016, http://worldoceanreview.com/en/wor-2/fisheries/state-of-fisheriesworldwide

Worm, B., M. Sandow, A. Oschlies, H. K. Lotze and R. A. Myers. 2005. "Global Patterns of Predator Diversity in the Open-Oceans." Science 309(5739): 1365-1369.

WTO. 2011, February 4. FISHERIES SUBSIDIES - ARTICLES I, II AND IV: Communication from the Republic of Korea (TN/RL/GEN/168/Suppl.1). Geneva, Switzerland: World Trade Organisation, https://docs.wto.org/dol2fe/ Pages/FE Search/FE S S009-DP.aspx?language=E\&CatalogueIdList=233959, 225142,135830,135836,135635,135613,95883,87456,99910,94811\&Current CatalogueIdIndex $=9 \&$ FullTextHash $=\&$ HasEnglishRecord $=$ True $\&$ HasFrench Record=True\&HasSpanishRecord $=$ True

WWF. 2017. "Fisheries in Transition.” World Wide Fund for Nature, http://wwf.panda. org/what_we_do/footprint/smart fishing/how we do this/sustainable markets new/ fip and fcps/

UN Department of Economic \& Social Affairs. 2015, June. Transitioning from the MDGs to the SDGs: Accountability for the Post-2015 Era: A Background Report by the CDP Subgroup on Accountability (CDP Background Paper No. 25 ST/ESA/2015/CDP/25). New York: United Nations, http://www.un.org/en/ development/desa/policy/cdp/cdp background papers/bp2015 25.pdf

UNEP. 2014. Sustainable Development Goals-Oceans (UNEP (DEPI)/RS.16 /INF.6.RS). Nairobi, Kenya: United Nations Environment Programme.

United Nations General Assembly (UNGA). 2016, February 12. Resolution adopted by the General Assembly on 22 December 2015 (A/RES/70/226). New York: United Nations General Assembly, http://www.un.org/ga/search/view_doc.asp? symbol=A/RES/70/226\&Lang=E

IIED. 2014. Fisheries and the Post-2015 Development Agenda (IIED Briefing). London: The International Institute for Environment and Development (IIED). IIED. 2016. "Mauritius, Sweden to Lead Consultations on SDG 14 Conference" 
(News Report). London: The International Institute for Environment and Development (IIED).

Ye, Yimin, Manuel Barange, Malcolm Beveridge, Luca Garibaldi, Nicolas Gutierrez and Alejandro Anganuzzi. 2017. "FAO's Statistic Data and Sustainability of Fisheries and Aquaculture: Comments on Pauly and Zeller." Marine Policy, accessed March 20, 2017, http://www.sciencedirect. com/science/article/pii/S0308597X17300921?via\%3Dihub\&ccp=y

Zhang, C. I., S. Kim, D. Gunderson, R. Marasco, J. B. Lee, H. W. Park and J. H. Lee. 2009. "An Ecosystem-based Fisheries Assessment Approach for Korean Fisheries." Fisheries Research 100(1): 26-41.

Zhang, C. I., A. B. Hollowed, J. B. Lee and D. H. Kim. 2011. "An IFRAME Approach for Assessing Impacts of Climate Change on Fisheries." ICES Journal of Marine Science 68(6): 1318-1328. 